\title{
Review: Acid Mine Drainage (AMD) in Abandoned Coal Mines of Shanxi, China
}

\author{
Zhaoliang Wang ${ }^{1,4, *}$, Yongxin $X u^{1,3, *} \mathbb{D}$, Zhixiang Zhang ${ }^{2}$ and Yongbo Zhang ${ }^{2}$ \\ 1 Department of Earth Sciences, University of the Western Cape, Cape Town 7535, South Africa \\ 2 College of Water Resources Science and Engineering, Taiyuan University of Technology, \\ Taiyuan 030024, China; zhangzhixiang@tyut.edu.cn (Z.Z.); zfstzhang@sina.com (Y.Z.) \\ 3 Institute of Africa Water Resources and Environment, Hebei University of Engineering, \\ Handan 056038, China \\ 4 Shanxi Qingze Sunshine Environmental Protection Technology Co. LTD., Taiyuan 030006, China \\ * Correspondence: wzliang0501@126.com (Z.W.); yxu@uwc.ac.za (Y.X.)
}

\section{check for} updates

Citation: Wang, Z.; Xu, Y.; Zhang, Z.; Zhang, Y. Review: Acid Mine Drainage (AMD) in Abandoned Coal Mines of Shanxi, China. Water 2021, 13, 8.

https://dx.doi.org/10.3390/w13010008

Received: 24 November 2020

Accepted: 19 December 2020

Published: 23 December 2020

Publisher's Note: MDPI stays neutral with regard to jurisdictional claims in published maps and institutional affiliations.

Copyright: () 2020 by the authors. Licensee MDPI, Basel, Switzerland. This article is an open access article distributed under the terms and conditions of the Creative Commons Attribution (CC BY) license (https: / / creativecommons.org/ licenses/by/4.0/).

\begin{abstract}
Excessive exploitation and massive coal mine closures have brought about extensive goafs in Shanxi where 8780 coal mines have been abandoned in the last 20 years. Acid mine drainage (AMD) poses severe environmental impact and has become a prominent problem in Shanxi abandoned coal mine areas, which has aggravated the shortage of water resources and threatened the safety of the local drinking water supply. The purpose of this review is to protect the precious water resources and maintain sustainable use in Shanxi coal mines and downstream. By retrieving and analyzing about 90 domestic and international publications, a critical review of the AMD research results in Shanxi abandoned coal mines is conducted from the perspective of the formation mechanism, migration and transformation, prediction, treatment and management. The results shows that pyrite is the prerequisite for the formation of AMD, oxygen is the inducement, water is the carrier, and $\mathrm{Fe}^{3+}$ and microorganisms are the catalyst. The roadway system and geological structure are the dominant control factors. Finally, current difficulties and future research are pointed out. It is necessary to further strengthen the systematic research on the geological and hydrogeological conditions of abandoned coal mines, and explore an efficient, cheap, environmental technology, and construct the pollution risk assessment model for the AMD treatment. This study provides a scientific basis for the comprehensive treatment and management of AMD in abandoned coal mines in Shanxi.
\end{abstract}

Keywords: acid mine drainage; abandoned coal mine; water pollution; groundwater; Shanxi province

\section{Introduction}

Nowadays, acid mine drainage (AMD) problems in abandoned coal mines have become a worldwide environmental concern. For example, in the Rio region of Spain, AMD has been a continuous pollution source of the Tinto River [1]. AMD formed by a large number of abandoned coal mines in the USA and all of the world has polluted rivers with a total length of about $23,000 \mathrm{~km}[2,3]$, causing serious environmental consequences [4-7]. AMD in the closed pits of the Witwatersrand mine in South Africa has become an important issue of national concern [8-10]. The AMD problems of abandoned coal mines are widespread in other countries such as the Makum coal mine in India [11], the Gangreung coal mine in South Korea [12], and the Douro coal mine in Portugal [13], which have caused serious damage to the local water resources and the water environment. In China, according to statistics from the China Coal Industry Association, the number of coal mines has been reduced from more than 80,000 in the peak period to about 5800 at the end of 2018 [14,15]. Unfortunately, the closed coal mines in China have caused a series of water environmental problems such as destruction of water resources and deterioration of water quality [16,17]. Therefore, it is necessary to conduct research on AMD in abandoned coal mines globally.

Over the years, AMD research on the impact, formation, migration, prediction and treatment has received extensive attention from scholars both nationally and internationally. 
For example, Banks and Banks [18] evaluated the environmental impact of AMD emissions from abandoned coal mines in the UK using relevant water quality data, and pointed out that AMD had already resulted in groundwater pollution and the pollution degree had become more serious as the water level continued to rise. Wood et al. [19] found that the surface water pollution was the most serious in the first few decades by 32 monitoring drainage points of the abandoned coal mine in the Midland Valley of Scotland. Studies have shown that the groundwater in Hongshan and Zhaili coal mines in Zibo, Shandong, China, was in cross strata pollution, resulting in the scrapping of hundreds of water supply wells, which directly threatening the water quality of Xuzhou's water supply source and the Grand Canal from Beijing to Hangzhou [20-22]. In the Green Valley coal mines (GVS) in Indiana, AMD caused an increase in the Total dissolved solids (TDS)of the entire area [23], $\mathrm{SO}_{4}{ }^{2-}$ reached up to $63,000 \mathrm{mg} / \mathrm{L}$, and metals such as $\mathrm{Pb}, \mathrm{Zn}, \mathrm{Cd}, \mathrm{Cr}, \mathrm{Ni}, \mathrm{Be}$, and $\mathrm{V}$ also increased significantly [24]. AMD outflowed from a large number of abandoned coal mines in the Stockett-Centerville area of the USA's polluted surface rivers [25]. AMD has had an irreversible impact on the environment. Plenty of studies have showed that AMD is produced as a result of the oxidation of pyrite with water and oxygen [26,27]. For the migration, Nassery and Alijani [28] confirmed that AMD from abandoned coal mines in the Zirab area in northern Iran promoted the dissolution of carbonate rocks, which was the main factor for the geochemical evolution of groundwater. Jiang et al. [29] studied and concluded that the oxidation of sulfide in coal-measure strata and the oxidation of sulfide in mineral deposits respectively input $0.27 \%$ and $20.5 \% \mathrm{SO}_{4}{ }^{2-}$ by the sulfur isotopes in the Wujiang River Basin. He et al. [30] confirmed that the continuous discharge of AMD from a closed coal mine in Hunan, China, into rivers has caused biological migration in the water system. Sun et al. [31] collected sediment samples for geochemical and microbial community analysis, and concluded that AMD generated from the upstream abandoned coal mines in southwestern China [32]. Wang et al. [33] selected small watersheds where AMD was relatively concentrated in the Zhijin abandoned coal mine area in Guizhou and studied the migration and transformation process of sulfate in AMD in karst areas. For prediction, Grodner [34] established a numerical model of groundwater flow in the Sigma coal mine in South Africa using MODFLOW (USGS, Reston, VA, USA), and predicted the water level rise of the AMD after the pit was closed. Bernd E [35] studied the chemical properties of groundwater around an abandoned open-pit coal mine in central Germany. $\mathrm{Xu}$ [36] studied the chemical reaction in the water flow path of closed coal mines and revealed the law of hydro-geochemical conversion using PHREEQC software (USGS, Reston, VA, USA). Many scholars have selected typical abandoned coal mines to predict the spatiotemporal process of the water level rebound [37-41]. A lot of efforts have been made to treat AMD. Sun [42] studied the rise mechanism of AMD water level in closed coal mines and proposed effective measures to protect water resources. Gitari et al. [43] treated the AMD of a coal mine using fly ash, achieving the goal of waste treatment. Song et al. [44] carried out a two-year in situ source treatment of AMD from an abandoned coal mine in central Tennessee, USA by using remote sensing and biogeochemical technology, and achieved successful results at a high cost. It can be seen that the treatment solution is only suitable for specific project situations [45]. Zhang et al. [46] treated AMD by using $\mathrm{Na}_{2} \mathrm{CO}_{3}$ modified fly ash, the research results provide technical support for the comprehensive utilization of AMD. Liu and Sun [47] clarified the groundwater pollution problem caused by a closed coal mine, and put forward some effective technical means and feasible prevention methods. Wei et al. [48] proposed that the development trend of the combination of directed source control and terminal treatment technology was a hotspot of AMD research in China in the future. All these results can provide theoretical basis for regional and local AMD evaluation and management.

Located in northern China, Shanxi Province is rich in coal resources, with six major coalfields including Datong, Ningwu, Xishan, Hedong, Qinshui and Huoxi from north to south (Figure 1). The output of raw coal accounts for $1 / 4$ of the whole country. It is an important energy and heavy chemical base in China, and plays a significant role in the 
sustainable development of the economy and society and energy security. There are 8 large river basins in Shanxi. According to statistics, the coal mine areas in Shanxi are $61,050 \mathrm{~km}^{2}$, accounting for $39.1 \%$ of the total area of the region. Over the years, with the continuing exploitation of coal resources in Shanxi, water environmental problems such as destruction of water resources and deterioration of water quality have become increasingly prominent. In recent years in particular, with the closure of 8780 coal mines, water pollution caused by AMD has become increasingly serious [49], which has aggravated the shortage of water resources and threatened the safety of the local drinking water supply in Shanxi.

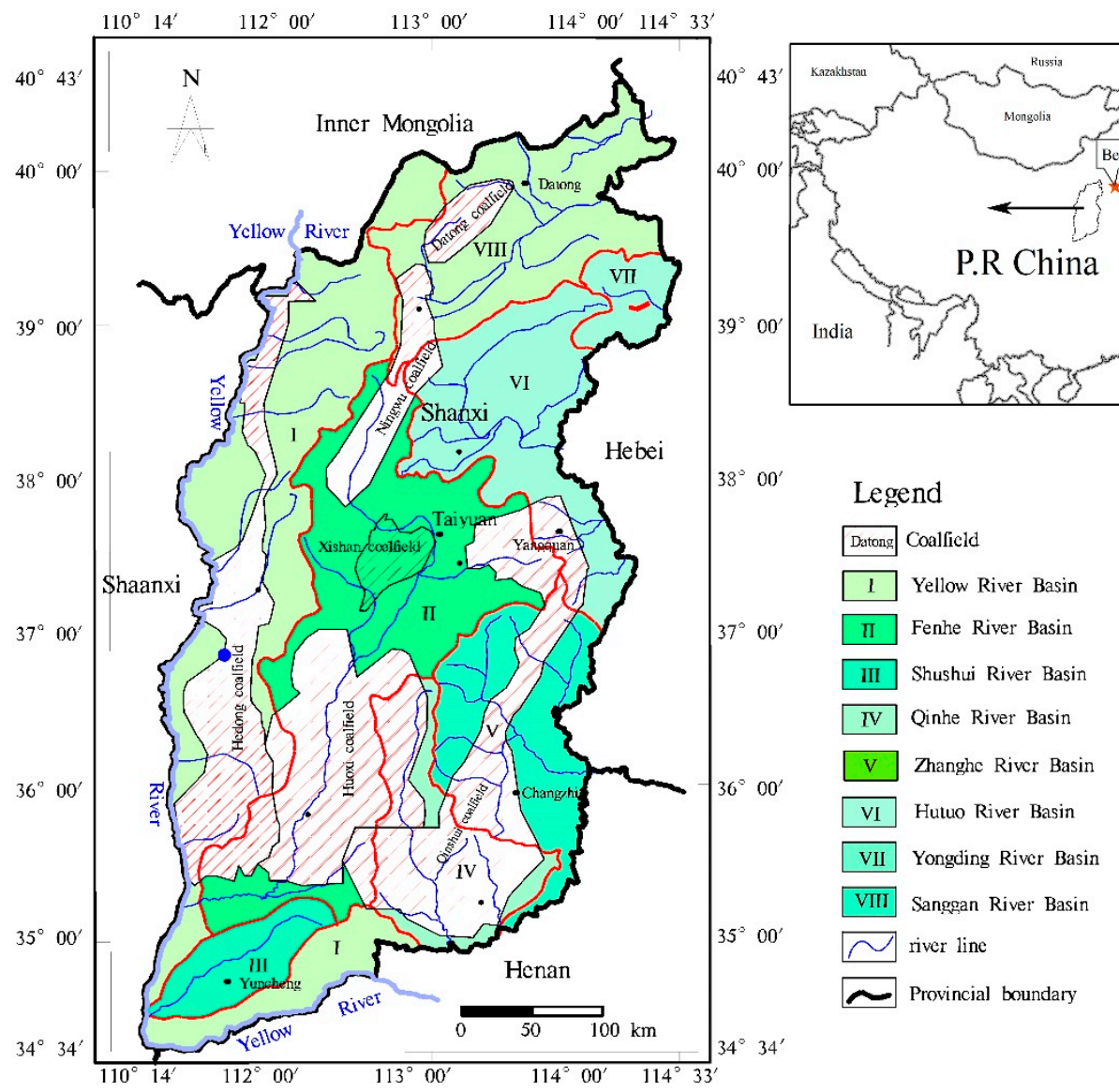

Figure 1. Six major coal fields in Shanxi.

On the basis of the previous investigations in the closed coal mines of Shanxi such as Datong coalfield [50,51], Yangquan coalfield [52,53], Taiyuan Xishan coalfield [54-56], etc., irreversible changes have taken place in the water-bearing medium structure, hydrodynamic field, chemical field and microorganism. The outflow of AMD has already affected the aquatic environment of downstream rivers. For example, a large amount of AMD have been stored in the small abandoned coal mines in Xishan coalfield [57]. These AMD leaked into the underlying karst aquifer through cracks and faults in the coal seam floor, moreover, the AMD in Niujiakou coal mine threatened the karst water quality of Jinci Spring [58]. Most unfortunately, a large amount of karst groundwater were dewatered in many pressurized coal mines [59], which further exacerbated the shortage of karst groundwater in the Jinci spring catchment.

According to a recent field investigation, the coal mine of Shandi Village in Yangquan, Shanxi, was closed in 2005, and the goaf was filled with AMD in 2009. Based on the monitoring data in 2013, the salinity, TDS, sulfate, and pH were $8274 \mathrm{mg} / \mathrm{L}, 4870 \mathrm{mg} / \mathrm{L}$, $5781 \mathrm{mg} / \mathrm{L}$, and 3.51, respectively [60]; at the end of 2016, the $\mathrm{pH}$ was 2-3, and the sulfate was 11,370-18,900 mg/L. AMD outflowed the surface and polluted the groundwater and surface water resources in the Shandi River Basin [58,61]. Some investigators $[52,62,63]$ 
pointed out that the leakage and outflow of AMD was the cause of the pollution in the Niangziguan Spring catchment in Shanxi. This case study was a warning and attracted more scholars to research the AMD from abandoned coal mines in Shanxi.

It can be seen that the mechanism of AMD formation in abandoned coal mines is very complex, which is closely related to hydrogeological conditions such as precipitation, surface water, aquifers and so on. The closure of coal mines in Shanxi mainly occurred after 2000 , and research on the water environment and ecological problems that may be induced by AMD in abandoned coal mines is still in its infancy. As one of the main coal energy bases in China, Shanxi has a large number of abandoned coal mines with a wide distribution and complex hydrogeological conditions. Furthermore, coal and water co-exist in Shanxi coal mines, which have close hydraulic connections with the 19 major karst springs in Shanxi. If the AMD problem continues to worsen, it will seriously threaten the safety of drinking water in the 19 spring catchments. Therefore, it is necessary to carry out further research on AMD in abandoned coal mines in Shanxi.

The purpose of this review is to protect the precious water resources and maintain sustainable utilization in Shanxi coal mines and downstream. By retrieving and analyzing about 90 national and international publications, a critical review of AMD research results in Shanxi abandoned coal mines was conducted from the perspective of the formation mechanism, migration and transformation, prediction, treatment and management. The current difficulties and future researches are pointed out. It is necessary to further strengthen the systematic research on the geological and hydrogeological conditions of abandoned coal mines, actively explore an efficient, cheap and environmental treatment technology, and formulate AMD risk assessment and early warning mechanism for abandoned coal mines. This review cements a scientific basis for the comprehensive treatment and management of AMD in abandoned coal mines in Shanxi.

\section{Overview of Acid Mine Drainage (AMD) Studies in Shanxi}

The major coal-bearing strata in Shanxi is dominated by the Taiyuan Formation of Upper Carboniferous and the Shanxi Formation of Lower Permian in Late Paleozoic, the coal reserves account for $98 \%$ of the region. The second coal-bearing strata in Shanxi is the Datong Formation of Middle Jurassic in Mesozoic and the coal-bearing construction of the Early Paleogene in Cenozoic.

Shanxi is the place with the most extensive karst distribution in northern China. There are 19 major karst springs (Figure 2) with stable flows and good water quality [49], which are convenient for centralized development and utilization, and they have become one of the important water supply sources for Shanxi energy bases. According to statistics, there are 265 centralized drinking water sources in Shanxi. The groundwater supply accounts for more than $90 \%$ of total water sources, of which approximately $83 \%$ is karst water. Over the years, researchers have conducted a certain degree of research on the relationship between AMD and water supply resources in abandoned coal mines in Shanxi, and achieved many important results, which have good practical value and can lay the foundation for research on AMD. 


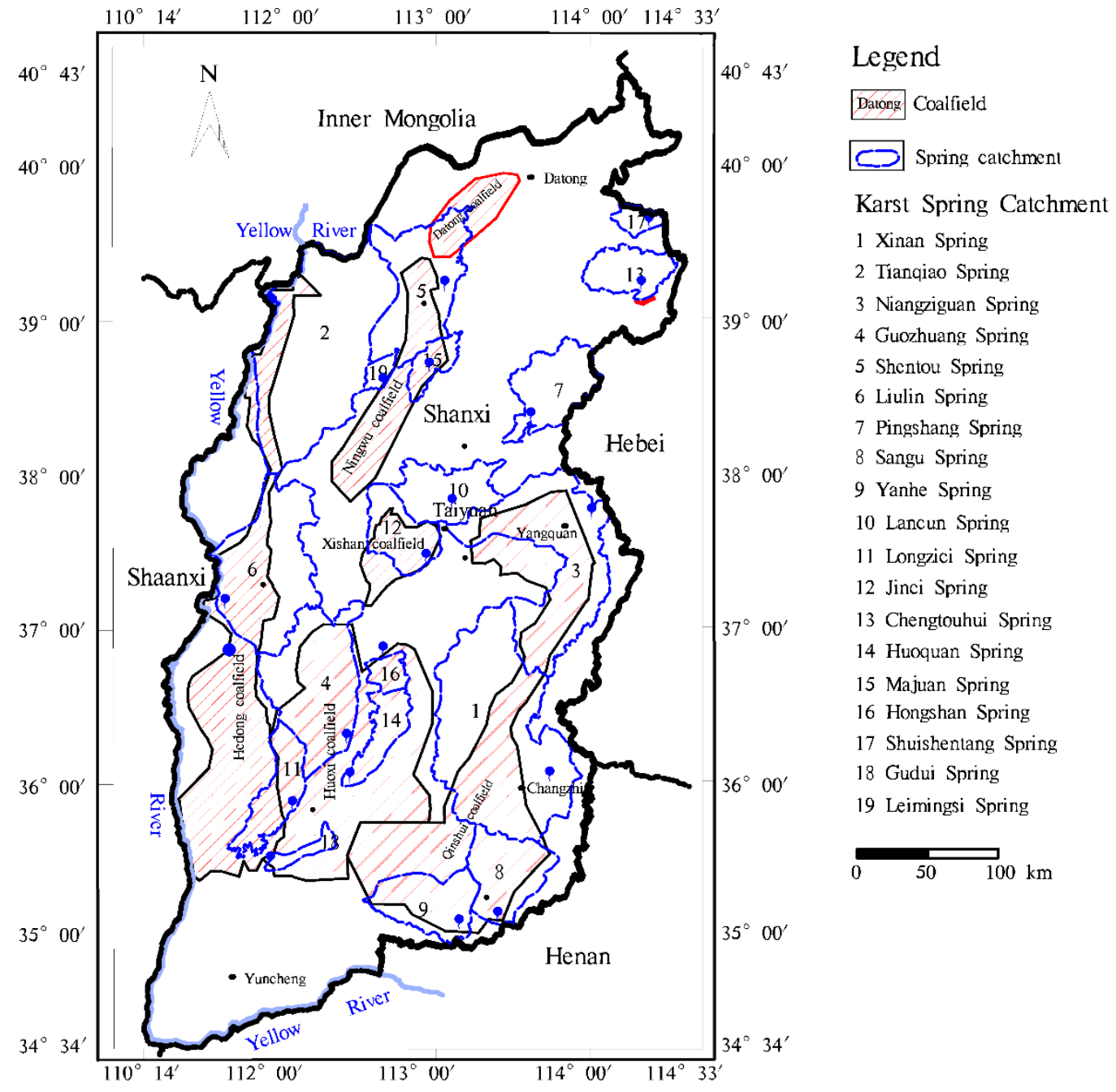

Figure 2. The 19 major karst springs in Shanxi.

\subsection{The Formation Mechanism of AMD}

\subsubsection{Source}

Based on the research results of AMD in abandoned coal mines in Shanxi, the exposed pyrite in the coal seams is the main cause. When pyrite reacts with oxygen and water, the products are Fe ions and sulfuric acid. The specific reaction equations are as follows:

$$
\begin{gathered}
2 \mathrm{FeS}_{2}+2 \mathrm{H}_{2} \mathrm{O}+7 \mathrm{O}_{2} \rightarrow 2 \mathrm{Fe}^{2+}+4 \mathrm{SO}_{4}{ }^{2-}+4 \mathrm{H}^{+} \\
12 \mathrm{FeSO}_{4}+6 \mathrm{H}_{2} \mathrm{O}+3 \mathrm{O}_{2} \rightarrow 8 \mathrm{Fe}^{3+}+12 \mathrm{SO}_{4}{ }^{2-}+4 \mathrm{Fe}(\mathrm{OH})_{3}
\end{gathered}
$$

Li et al. [64] conducted a certain sampling analysis on the basis of the collected data. The results showed that the $\mathrm{SO}_{4}{ }^{2-}$ from gypsum accounts for about $30 \%$, and the $\mathrm{SO}_{4}{ }^{2-}$ from oxidation of pyrite accounts for about $60-70 \%$. The dissolution of gypsum and oxidation of sulfide in aquifers were the main causes for the high concentration of $\mathrm{SO}_{4}{ }^{2-}$. Zhao et al. [56] confirmed that the organic sulfur in coal can also generate acid after its oxidation, which aggravates the decrease of $\mathrm{pH}$ to a certain extent; when the sulfur content is $>5-7 \%$, the $\mathrm{pH}$ is $6-5.5$; when the sulfur content is $>7-9 \%$, the $\mathrm{pH}$ is $5.5-3.5$; when the sulfur content is $>9-11 \%$, the $\mathrm{pH}$ is 3 ; when the sulfur content is $>12 \%$, the $\mathrm{pH}$ is below 2.5. According to qualitative analysis by scholars [65], AMD in abandoned coal mines in Shanxi is also generated by a series of oxidation reactions involving the pyrite mixed in coal seams, oxygen and water. 
The above results show that there are still few studies on the formation of AMD in Shanxi abandoned coal mines, and there is a big gap between Shanxi and domestic as well as international cases, such as inconsistent descriptions of the reaction process and insufficient consideration of influencing factors (especially microorganisms such as Acidophilus thiobacillus ferrooxidans, A.f) which limits the theoretical development of AMD's formation mechanism.

The authors of this article believe that $\mathrm{S}_{2}{ }^{2-}$ and $\mathrm{Fe}^{2+}$ exist simultaneously on the surface of pyrite in the $\mathrm{FeS}_{2}+\mathrm{H}_{2} \mathrm{O}+\mathrm{O}_{2}$ system in Shanxi abandoned coal mines (Figure 3). According to the principle of redox, the reducibility of $\mathrm{S}_{2}{ }^{2-}$ is greater than that of $\mathrm{Fe}^{2+}$, that is, the $\mathrm{S}_{2}{ }^{2-}$ in water first oxidizes with $\mathrm{O}_{2}$. The specific reaction equations are as follows:

$$
\begin{gathered}
\mathrm{S}_{2}{ }^{2-}+\mathrm{O}_{2}+\mathrm{OH}^{-} \rightarrow \mathrm{S}_{2} \mathrm{O}_{3}{ }^{2-}+\mathrm{H}^{+} \\
2 \mathrm{~S}_{2} \mathrm{O}_{3}{ }^{2-}+0.5 \mathrm{O}_{2}+2 \mathrm{H}^{+} \rightarrow \mathrm{S}_{4} \mathrm{O}_{6}{ }^{2-}+\mathrm{H}_{2} \mathrm{O} \\
\mathrm{S}_{2} \mathrm{O}_{3}{ }^{2-} \rightarrow \mathrm{S}+\mathrm{SO}_{3}{ }^{2-} \\
\mathrm{S}+1.5 \mathrm{O}_{2}+\mathrm{H}_{2} \mathrm{O} \rightarrow \mathrm{SO}_{4}{ }^{2-}+2 \mathrm{H}^{+} \\
\mathrm{SO}_{3}{ }^{2-}+0.5 \mathrm{O}_{2} \rightarrow \mathrm{SO}_{4}{ }^{2-}
\end{gathered}
$$

Since $\mathrm{S}_{2}{ }^{2-}, \mathrm{S}^{0}, \mathrm{~S}_{2} \mathrm{O}_{3}{ }^{2-}, \mathrm{S}_{4} \mathrm{O}_{6}{ }^{2-}$, and $\mathrm{SO}_{3}{ }^{2-}$ have a greater ability to obtain electrons than $\mathrm{Fe}^{2+}$, in a closed environment with limited dissolved oxygen, the reaction rate is basically negligible, and iron basically exists in the form of $\mathrm{Fe}^{2+}$. Even if a large amount of dissolved oxygen exists, the reaction rate is quite slow. The excess $\mathrm{Fe}^{2+}$ reacts with the remaining $\mathrm{O}_{2}$ after the reaction of Equations (3)-(7):

$$
\mathrm{Fe}^{2+}+0.25 \mathrm{O}_{2}+\mathrm{H}^{+} \rightarrow \mathrm{Fe}^{3+}+0.5 \mathrm{H}_{2} \mathrm{O}
$$

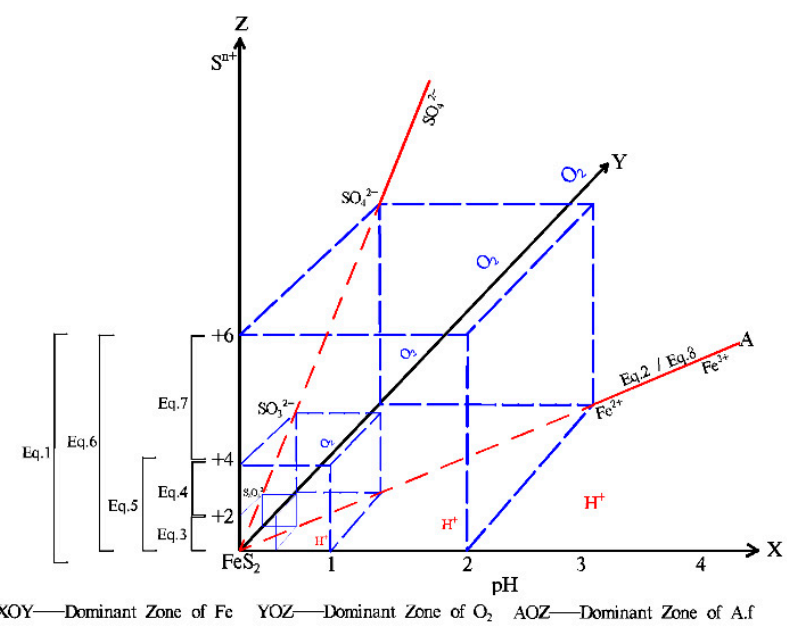

Figure 3. $\mathrm{FeS}_{2}+\mathrm{H}_{2} \mathrm{O}+\mathrm{O}_{2}$ reaction diagram in abandoned coal mines of Shanxi.

If microorganisms on the surface of pyrite such as Acidophilus thiobacillus ferrooxidans [66] are extremely active, the microorganisms obtain electrons firstly and combine with $\mathrm{O}_{2}$, pyrite will be oxidized and leach a large amount of $\mathrm{Fe}^{3+}$ simultaneously. The reaction equations are as follows:

$$
\begin{gathered}
4 \mathrm{Fe}^{2+}+\mathrm{O}_{2}+4 \mathrm{H}^{+}+\text {A.f } \rightarrow 4 \mathrm{Fe}^{3+}+2 \mathrm{H}_{2} \mathrm{O} \\
\mathrm{FeS}_{2}+\mathrm{Fe}_{2}\left(\mathrm{SO}_{4}\right)_{3} \rightarrow 3 \mathrm{FeSO}_{4}+2 \mathrm{~S}
\end{gathered}
$$

The $S$ generated by the above reactions is oxidized as the energy source of A.f:

$$
2 \mathrm{~S}+3 \mathrm{O}_{2}+2 \mathrm{H}_{2} \mathrm{O}+\mathrm{A} . \mathrm{f} \rightarrow 4 \mathrm{H}^{+}+2 \mathrm{SO}_{4}{ }^{2-}
$$


Under the action of microorganisms, the production rate (Equation (9)/Equation (8)) of $\mathrm{Fe}^{3+}$ is 105-108 times higher than that of sterile environment [67]; while the number of microorganisms is small, the activity is weak, and the two environments co-exist. When the $\mathrm{S}_{4} \mathrm{O}_{6}{ }^{2-}$ is produced, the $\mathrm{Fe}^{3+}$ can also participate in the oxidation reaction. The reaction formula is as follows:

$$
\mathrm{S}_{4} \mathrm{O}_{6}{ }^{2-}+3 \mathrm{Fe}^{3+}+2.75 \mathrm{O}_{2}+4.5 \mathrm{H}_{2} \mathrm{O} \rightarrow 3 \mathrm{Fe}^{2+}+4 \mathrm{SO}_{4}{ }^{2-}+9 \mathrm{H}^{+}
$$

Therefore, we come to a simplified mechanism of AMD formation in abandoned coal mines, that is, pyrite is the prerequisite, oxygen is the inducement, water is the carrier, $\mathrm{Fe}^{3+}$ and microorganisms are the catalysts.

At a $25{ }^{\circ} \mathrm{C}$ (1atm), the solubility of dissolved oxygen is basically maintained at 8-10 $\mathrm{mg} / \mathrm{L}$, and the distribution of underground microorganisms is not artificially controlled. Hence, it can be inferred that the AMD, where the pyrite is rich, the coal is buried to a shallow extent and mine water circulates faster, is more likely to be formed. This is very helpful in determining the location of abandoned coal mine which is prone to the outflow of AMD. It must be pointed out that the No. 2, 3, and 5 coal seams of the Datong coalfield contain very low pyrite with the form of limonite, although buried to a shallow extent [68]. Therefore, the mine water may be acidic or neutral, depending on the content of pyrite in the coal seams [69] and dissolution depletion [70]. In addition, the complex sources of water that forms AMD, including precipitation, surface water, the overlying loose pore water, coal-bearing fissure water of adjacent mines, and underlying karst water, may all enter into the goaf. These different types and rates of water circulation also bring create difficulty in research on AMD.

\subsubsection{Water Filling Process}

As the water hazards in Shanxi coal mines are more prominent, scholars have focused on the water-filling process of the conduction of the overlying pore and fractured aquifer and the underlying karst aquifer by the factors such as the height of the water-conducting fissure zone, floor water inrush, water-conducting fault, and collapse column, and many results have been achieved. For example, researchers [71,72] systematically studied the development and evolution of the water-conducting fissure zone, and explored in depth the law of water filling of overlying aquifers caused by different mining thicknesses and buried depth. By means of hydrogeological and numerical simulation methods, Kang [73] researched the water-conducting fissure zone of Nancha coal mine in Ningwu coalfield, and concluded that the main water-filling channels are the water-conducting fissure zone formed by roof collapse, the water-conducting fissure zone, faults, collapse columns and poorly sealed boreholes. It reveals that the water accumulation of the goaf is a dynamic process with diversity.

In recent years, as the mining depth of Shanxi coal mines has changed from shallow to deep, research on the limestone aquifer beneath the coal seams as the main water source has also received increasing attention. For example, Li [74] summarized the factors affecting the water richness of limestone aquifers in the Lower Fengfeng Formation in Shanxi six major coalfields, and believed that it was the main aquifer for water inrush from the coal seam floor of the lower group of coal, and pointed out the faults and collapse columns in each coal mine can be used as water diversion channels for groundwater convergence, which accelerates the water-filling process. It showed that the content of previous researches has developed from the height of the water-conducting fissure zone to the relationship between rock mechanical properties and water-conducting channels, which has an important guiding role in the study of the water filling process in Shanxi abandoned coal mines.

However, the above study of water filling process is for the needs of coal mine safety production, and it is a pumping process for groundwater. On the contrary, water accumulation in the phase of abandonment of coal mines is an incremental process, which is a dynamic process of water filling-water accumulation-outflow. 
According to our field investigation, the water filling process of AMD in the Shanxi abandoned coal mines has its own uniqueness: the developed roadway systems are highly involved. The developed roadway systems are left behind by underground mining, they not only run through the water filling channels of different mining levels vertically, but also connect the water accumulation space of different mining areas at a mining level, forming the strongest runoff corridor for AMD. After the coal mines were completely abandoned, the shaft and roadway were not effectively blocked, the goaf was not filled, and the runoff mode of groundwater had an essential change: at the same mining level, the water accumulation space of different mining areas was connected in series, which accelerated the accumulation of groundwater; at different mining levels, the water filling channel run through the upper and lower mining levels, so that the accumulated water from the upper level enters into the lower level. This kind of water-filled corridor breaks through the limits of water-conducting channels such as water-conducting fissure zone, floor water inrush, fault water-conducting, collapse column, etc. The groundwater flow field and dynamic field have undergone tremendous changes, but these have not been concerned by researchers. In fact, although the research on the impact of the roadway systems on AMD in Shanxi abandoned coal mines has not been reported so far, it has a great theoretical guiding significance for the water-filling process of AMD.

\subsubsection{Water Gathering Space}

Theoretically, when there is no water source in the goaf or the amount of water discharged from the goaf is greater than the amount of water filled, there will be no water in the goaf; when the amount of water filled in the goaf is greater than the amount of water discharged from the goaf, the goaf will be partially or fully filled with water. It can be seen that not all of the goaf can be accumulated with water, and only the goaf with accumulated water can be called AMD water-gathering spaces.

Up to now, the goaf areas formed by coal mining in Shanxi are about 20,000 $\mathrm{km}^{2}$, equivalent to $1 / 8$ of Shanxi's land area $\left(156,700 \mathrm{~km}^{2}\right)$. The goaf with accumulated water is prone to cause water inrush accidents during coal mining, which has attracted much attention by scholars.

Some scholars conducted research on the water accumulation problem in the goaf of Shanxi abandoned coal mines, which provide a scientific basis for the safe production. Based on the collected data from 42 water accumulation areas of 28 coal mines in Qinshui coalfield, Xiong and Wang [75] put forward the important term of the water accumulation coefficient by laboratory research and theoretical analysis. Di [76] discussed the storage and distribution law of water accumulation in the goaf of Datong-Ningwu coalfield, and believed that the geological structure is the dominant factor controlling the distribution of AMD. Zhu [77] confirmed that the partial sections of the goaf can gradually accumulate water because it is located at a low level in the inclined direction of the coal seam, and there is no roadway to drain mine water. Wen and Zhang [78] detected water accumulation in a Shanxi large coal mine by using transient electromagnetic and direct current methods, and delineated the water accumulation area of the goaf of No. 3 coal seam. Xu [79] found out the location and scope of the goaf and the water-filled area of the coal mine using a transient electromagnetic prospecting method.

The above research results provide a reliable basis for the flood prevention, and also point out the direction and methods for the research of the water-gathering space of AMD. However, the purpose of these research results is to ensure safe production, without considering the water ecological environment problems caused by AMD in abandoned coal mines. In fact, the geological structure is the dominant factor that controls the distribution of AMD [80]. The focus of our attention is the goaf which can gather AMD in abandoned coal mines. Therefore, research on water-gathering spaces of AMD and geological structure still needs to be further strengthened. 


\subsection{Migration and Transformation}

Most of Shanxi's abandoned coal mines were closed after 2000, and the water environment problems caused by AMD gradually emerged. At present, there is little research on the hydrochemical evolution of AMD in abandoned coal mines during the migration process. Regarding the research on the migration law of AMD pollutants in groundwater, some theories and opinions have been put forward only in individual coal mines. For example, Zhao et al. [51] studied the chemical composition, phase composition and migration characteristics of harmful elements of AMD of the Malan coal mine in Xishan coalfield using adsorption experiments and PHREEQC software [81-83], and pointed out that the migration of harmful elements in AMD is mainly controlled by $\mathrm{pH}, \mathrm{Fe}-\mathrm{Al}-\mathrm{Mn}$ content and mineral composition of water particles. By using the same methods, Sun et al. [84] determined the AMD, sediments, and content of rare earth elements in coal samples in two different coal mines in Shanxi, and revealed the contribution of $\mathrm{pH}$, hydroxide (Fe-Al-Mn), sediments and complexation, etc. in controlling the distribution pattern of rare earth elements in AMD.

It can be seen that the hydrochemical evolution of AMD is concentrated in the migration and transformation laws of $\mathrm{pH}$ and metal elements, which points out a direction for researchers. However, previous research methods were relatively simple. Strictly speaking, the Malan and Sitai coal mines are still mining the lower coal seam, which is different from the completely abandoned coal mines. Compared with the coal mine of Shandi Village, the concentration of metal ions in AMD at sampling points of the former two coal mines is lower, indicating that the characteristics of hydrochemistry in the mining period and the abandoned period are quite different. In particular, the difference of the sulfate concentration in different stages is $10,000 \mathrm{mg} / \mathrm{L}$, which has a greater impact on the hydrochemical equilibrium. Although the previous results have certain reference significance, it is difficult to fully promote research on all abandoned coal mines in Shanxi.

In our opinion the migration and transformation of AMD is a comprehensive process of active participation of multi-mineral and multi-gas components under the synergistic action of oxidation-reduction, dissolution-precipitation, adsorption-desorption, ion exchange, complexation and microbial action. Adsorption experiments and PHREEQC software make it difficult to achieve this comprehensive process. For example, many minerals in the surrounding rock have a buffering effect on AMD. Pyrite is the prerequisite of AMD, and the pyrite reserves determine the acid production capacity. When the acid production capacity exceeds the neutralization and digestion of alkaline minerals, the $\mathrm{pH}$ will be increasingly low; when the dissolved heavy metals exceed the adsorption of viscous minerals, the metal ions will become higher and higher.

The chemical reaction equations of common minerals in coal seams of Shanxi abandoned coal mines are as follows:

Calcite: $\mathrm{CaCO}_{3}+2 \mathrm{H}^{+} \rightarrow \mathrm{Ca}^{2+}+\mathrm{CO}_{2}+\mathrm{H}_{2} \mathrm{O}$

Dolomite: $\mathrm{CaMg}\left(\mathrm{CO}_{3}\right)_{2}+4 \mathrm{H}^{+} \rightarrow \mathrm{Ca}^{2+}+\mathrm{Mg}^{2+}+2 \mathrm{CO}_{2}+2 \mathrm{H}_{2} \mathrm{O}$

Muscovite: $\mathrm{KAI}_{2}\left(\mathrm{AISi}_{3} \mathrm{O}_{10}\right)(\mathrm{OH})_{2}+\mathrm{H}^{+}+1.5 \mathrm{H}_{2} \mathrm{O} \rightarrow \mathrm{K}^{+}+1.5 \mathrm{AI}_{2} \mathrm{Si}_{2} \mathrm{O}_{5}(\mathrm{OH})_{4}$

Biotite: $\mathrm{K}(\mathrm{Mg}, \mathrm{Fe})_{3} \mathrm{AISi}_{3} \mathrm{O}_{10}(\mathrm{OH})_{2}+7 \mathrm{H}^{+} \rightarrow \mathrm{K}^{+}+3\left(\mathrm{Mg}^{2+}, \mathrm{Fe}^{2+}\right)+\mathrm{AI}(\mathrm{OH})_{3}+2 \mathrm{SiO}_{2}+3 \mathrm{H}_{2} \mathrm{O}$ Plagioclase: $\mathrm{Na}_{0.7} \mathrm{Ca}_{0.3} \mathrm{AI}_{1.3} \mathrm{Si}_{2.7} \mathrm{O}_{8}+1.3 \mathrm{H}^{+}+1.3 \mathrm{H}_{2} \mathrm{O} \rightarrow 0.3 \mathrm{Ca}^{2+}+0.7 \mathrm{Na}^{+}+1.3 \mathrm{AI}(\mathrm{OH})_{3}$ $+2.7 \mathrm{SiO}_{2}$

Illite: $\mathrm{K}_{\mathrm{m}} \mathrm{Na}_{\mathrm{n}} \mathrm{Ca}_{\mathrm{o}} \mathrm{Mg}_{\mathrm{p}} \mathrm{Fe}_{\mathrm{q}} \mathrm{AI}_{\mathrm{r}} \mathrm{SiO}(\mathrm{OH})_{2}+(0.5 \mathrm{r}+4 \mathrm{~s}-12) \mathrm{H} 2 \mathrm{O}+(22-4 \mathrm{~s}-3 \mathrm{r}) \mathrm{H}^{+} \rightarrow \mathrm{mK}^{+}+\mathrm{nNa}^{+}$ $+\mathrm{oCa}^{2+}+\mathrm{pMg}^{2+}+\mathrm{qFe}^{3+}+0.5 \mathrm{r}\left(\mathrm{AI}_{2} \mathrm{O}_{3} \cdot 2 \mathrm{SiO}_{2} \cdot 2 \mathrm{H}_{2} \mathrm{O}\right)+(\mathrm{s}-\mathrm{r}) \mathrm{H}_{4} \mathrm{SiO}_{4}$

If there are insufficient acid-consuming minerals in the goaf, AMD will be formed. However, the main lithology of Shanxi coal-bearing strata are limestone, sandstone, mudstone and shale; among them, $\mathrm{K}_{2}-\mathrm{K}_{4}$ limestones have a good neutralization effect on acid, and sandstone, mudstone and shale are rich in clay minerals (kaolinite, montmorillonite, hydromica) with a good adsorption effect on metal ions. It can be seen that many factors control the evolution of AMD's hydrochemistry and the release of heavy metals. However, 
no studies have been reported on the environmental effects and release mechanism of heavy metals in Shanxi abandoned coal mines.

When the AMD in the goaf outflows to the surface water, it enters into an open environment from a relatively closed environment, and the hydrochemical balance is broken. Its water quality migration and transformation is accompanied by reactions such as oxidation-reduction, dissolution-precipitation, adsorption-desorption, and ion exchange, complexation, microorganisms, etc., and there are multiple minerals and gas components involved. The current research mainly focuses on the investigation of water quality in the polluted areas after the coal mines were closed, and there is a lack of targeted research on the migration and transformation of AMD in specific closed coal mines. A lot of work should be done to study the migration and transformation of AMD in Shanxi abandoned coal mines, and it is necessary to further strengthen the study of the respective effects of these factors and the coupling effects among multiple factors.

\subsection{Prediction}

In terms of time cycle, AMD will be discharged through different channels after the completion of a water filling and water gathering process of the goaf in Shanxi. Zhang et al. [49] pointed out that AMD leaked into the underlying karst aquifer; Li and Wang [58] believed that the outflow of AMD polluted surface water; some scholars believed that AMD was discharged simultaneously to groundwater and surface water $[52,62,63]$. In fact, the water environment problems in Niangziguan Spring [60] and Jinci Spring [58] caused by AMD are unavoidable problems in water source protection. At present, a large number of valuable research results have been accumulated for the prediction of water accumulation in the goaf of Shanxi. For example, Xiong et al. [75] analyzed the hydrogeological conditions and possible causes of water inrush of the Qinshui coalfield, and proposed a concept of water accumulation coefficient, and determined the water accumulation in the goaf. Di [76] predicted the water accumulation in the goaf of Tongxin coal mine using the water accumulation coefficient; Kang [73] analyzed the water accumulation in the Nancha coal mine of Ningwu coalfield using a comprehensive method. Wen [85] accurately determined the range of water accumulation using the combination of a transient electromagnetic exploration method and direct current method, and predicted the amount of water accumulation in the goaf. These theoretical methods and practical experience from research provide a reliable theoretical basis for Shanxi AMD prediction.

To sum up, the above research can solve the water accumulation problem in AMD, but there are still some shortcomings in the research on the proportion of the AMD outflow, how long it can outflow, and where it can outflow in Shanxi abandoned coal mines. As mentioned above, the coal mine of Shandi Village was closed in 2005, and the goaf was filled with AMD in 2009 [60]. At present, scholars have not reported any researches on AMD's prediction in Shanxi abandoned coal mines. From a regional perspective, the AMD environmental problems in Shanxi are mainly concentrated in Datong mining area [50,51], Yangquan mining area [52,53], and Taiyuan Xishan mining area [55,56]. A further study is firstly needed as to why these coal-mining areas became AMD discharge sites. From a single coal mine, AMD is discharged through different channels, and the spatial distribution of discharge points must have their own particularity. Due to the existence of many abandoned coal mines in Shanxi, it is more necessary to conduct research on the proportion of the AMD outflow, how long it can outflow, and where it can outflow. These studies can gain precious time for AMD prevention and provide precise spatial instructions for AMD prevention and control areas (points).

\subsection{Treatment}

AMD's pollution is a global problem and has received extensive attention from scholars globally. For many years, as a result of the lure of high profit, environmental protection was generally neglected in coal mining, and the governance has no corresponding plan for the treatment of the closed pit. 
At the same time, due to the constraint of economy and technology in Shanxi, the AMD treatment is mostly concentrated in the centralized treatment of mine water during coal mining. Most coal mines treated the AMD by using lime and limestone neutralization as well as sedimentation methods in the form of sewage treatment stations. Recently, the reverse osmosis membrane has been added with the upgrading of the standard. At present, scholars have studied the AMD treatment in Shanxi abandoned coal mines by different methods. For example, Yin [86] and Liu [87] remedied AMD using the bacterial strain from loess and sludge of sewage. The tests showed that the maximum removal rate of sulfate in AMD was $81.9 \%$ and $64.75 \%$, respectively. Yang et al. [88] simulated the bioremediation of AMD in natural drainage mines using an open reactor in laboratory, and explored the feasibility of using natural drainage mines with the appropriate amounts of microorganisms and required carbon sources to remedy AMD. Zhao et al. [89] used a soil column leaching experiment to adsorb sulfate radicals in AMD, and the results showed that under the condition of a certain volume of loess, the processing capacity is Malan loess $>$ Lishi loess $>$ paleosol. Zhou et al. [90] used $\mathrm{NaOH}$ neutralization method to treat AMD, and gained better results. Taking sand as a repair material for AMD, Wu et al. [91] studied the removal efficiency of sulfate ions in AMD by different particles, and the results showed that the removal efficiency was up to $62.36 \%$ for less than $0.075 \mathrm{~mm}$. By using Malan loess, iron slag and carbon steel slag as adsorbent, the effect of solid-liquid ratio, contact time, initial concentration, temperature and $\mathrm{pH}$ on sulfate adsorption in AMD were studied [92,93], and the results indicated that acid conditions were favorable for sulfate adsorption. Wan and Li [94] introduced a new carbon source corncob for Sulfate Reducing Bacteria (SRB) to treat AMD, discussed the resource utilization of wastewater from sulfate mines, and verified the feasibility of biological treatment. Lu et al. [95] studied the effect of modified red mud on AMD adsorption. Wang et al. [96] and Zhang [97] proposed the method of treating AMD using "loess-wetland-plant-microbial ecosystem", and discussed its feasibility and advantages. These research works have a significant guiding role in dealing with AMD problems in Shanxi abandoned mines, but they are basically at the state of laboratory experiments and theoretical research.

Due to the variety and high concentration of metals in AMD, large-scale treatment is very difficult. The aforementioned treatment research focuses on neutralization, permeable membrane filtration, adsorption, microbial method, etc. Although the mentioned methods have their applicability in certain scenarios, they have limitations in Shanxi abandoned mines. At present, the permeable membrane filtration method has the advantages of no waste generation, fast separation speed, and high selectivity. However, it faces several problems of polarization, scaling and corrosion. As a treatment process with low energy consumption and simple operation, the adsorption method only realizes the transfer of pollutants and also has the secondary pollution. A microbial method has the advantages of low cost, strong applicability, great potential, and no secondary pollution, but it takes a long time for domestication and lacks an economic organic carbon source.

The above research showed that technical limitations were exposed in AMD's treatment of Shanxi. Most scientific researchers studied the removal of pollutants in AMD by a single method. There is not a successful case for the AMD treatment in Shanxi abandoned coal mines, and the treatment technology has not been applied in practice and engineering.

The treatment of groundwater pollution caused by AMD in Shanxi abandoned coal mines has not received enough attention. Therefore, AMD has caused serious water pollution to the surrounding environment and a potential threat to the safety of the downstream drinking water. The research on the comprehensive treatment of AMD in Shanxi abandoned coal mines is of great significance to prevent water environmental effects and drinking water safety issues that are induced by AMD. Thus, exploring a cheap, efficient, environmental treatment technology for AMD will become a hotspot. 


\subsection{Management}

Through investigation and data verification, we found that the main measures were shaft plugging and tunnel filling when the coal mines in Shanxi were closed, but these measures cannot prevent the formation and discharge of AMD. Due to the lack of AMD monitoring data in Shanxi abandoned coal mines, the damage to groundwater cannot be measured. Up to now, exclusive specifications and regulations have not been promulgated for AMD management, a technical chart has been absent for AMD risk management, and an AMD risk early warning mechanism has not been formulated for abandoned coal mines.

It can be seen that the situation of AMD management in Shanxi abandoned coal mines is still severe, and policies and regulations for AMD management are still lacking. It is urgent to strengthen research on the risk assessment, early warning mechanism and management process of AMD in Shanxi abandoned coal mines, and provide technical support for the formulation of relevant policies and regulations. It is of great significance for standardizing AMD management and ensuring the water ecological environment as well as drinking water safety in abandoned coal mines.

\section{Problems and Difficulties}

With the continuous increase in the number of Shanxi abandoned coal mines, environmental problems such as the destruction of water resources and the deterioration of water quality caused by AMD are becoming an urgent topic for research. Scholars have accumulated rich experiences in Shanxi coal mines in the study of water inrush mechanisms, exploration of hydrogeological conditions, mining under pressure, decompression drainage, grouting for water blocking and curtain closure, and water resources evaluation and management, and achieved a series of important research results. Since the existing theories, technologies and methods are mainly for newly-built and producing mines, there are still many doubts and difficulties in the research of AMD in Shanxi abandoned coal mines that need to be solved and overcome, which are mainly reflected in the following aspects.

\subsection{Distribution of $A M D$}

Pyrite is a common widely distributed mineral in coal-bearing strata, but there is no detailed study on the occurrence of pyrite in Shanxi. The content of pyrite in the No. 2, 3, 5 coal seams of Datong coalfield is very low [68], and AMD is not easy to form. It can be seen that simply saying that the pyrite in the coal-bearing strata in Shanxi can cause AMD problems seems to be insufficient. Therefore, the occurrence law and spatial distribution characteristics of pyrite in Shanxi coal-bearing strata are worthy of further study.

Among the six major coalfields in Shanxi, only the Datong coalfield, Qinshui coalfield, and Xishan coalfield emerge AMD problems. Their common point is that the coal seams are exposed and the mining areas were cut by rivers, so it can be seen that the surface water plays an irreplaceable role as a carrier of oxygen. Due to the complex sources of AMD, including precipitation, surface water, overlying loose pore water, coal-bearing fissure water of adjacent mines, and underlying karst water, they may all enter into the goaf, and their different types and rates of water circulation also bring great difficulty to the AMD research. AMD has close hydraulic connection with surface water and groundwater, but there is little research on the hydraulic connection between them. The hydraulic connection of AMD with surface water and groundwater is of great guiding significance for determining the regional distribution of $\mathrm{AMD}$, and further investigation and research are needed.

\subsection{High Participation in Roadway System}

As a runoff gallery, the groundwater fluid in the roadway system presents a significant state of the conduit flow, and the roadway system extends to all directions. Its special state determines that the groundwater fluid of abandoned coal mines is different from the fissure flow in aquifers. In terms of groundwater simulation in mining areas, the current focus is to simulate the seepage field of fractured media. In fact, a multi-layer 
and multi-channel flow is formed in the abandoned coal mine by the overlapping of the fissure flow in the water-conducting fissure zone and the conduit flow in the abandoned roadway. The relationship between the input and output of the system is directly or indirectly determined by the geology, roadway and fissure. However, these factors appear to be random and uncertain, and this kind of runoff corridor breaks through the theory and model of groundwater seepage, making it difficult for generalization, analysis and prediction, so the research results are rarely reported in Shanxi. Therefore, it is necessary to study the dynamic evolution of groundwater flow field with high participation of roadway system in Shanxi abandoned coal mines.

\subsection{Effective Water Gathering Space}

It is of great significance to carry out research on the detection of AMD's watergathering space. Due to the hidden characteristics of water accumulation in the goaf, its spatial distribution pattern (boundary, shape of water accumulation) and occurrence law are very complicated; the water volume presents non-linearities and time variation, and the parameters such as water head and coefficient of water accumulation are difficult to determine. These factors cause great problems for the detection of AMD.

In addition, the detection results of a single coal mine or a certain goaf are limited by hydrogeological conditions, so it is difficultly to apply in other goaf. Therefore, it is necessary to carry out research on AMD's effective water gathering space. Theoretically speaking, the goaf will easily form a water-gathering space at the working face of the lower coal level, the two wings of the middle and lower anticlines, the syncline axis and the lower plate of the positive fault. Geological structure is the dominant factor that controls the distribution of water accumulation in the goaf. Hence, study on the inner relation between geological structure and AMD's effective water gathering space is further needed.

\subsection{Discharge Channels}

According to field survey, most of the closed coal mines are in the water-filling and water-gathering stages. The previous literatures only qualitatively reported that AMD had recharged into the local coal-bearing aquifers and directly outflowed to the surface water after coal mines were closed. However, the researchers did not further discuss how to recharge and discharge.

As typical Carboniferous-Permian coal-accumulating area in northern China, Shanxi coal seams have close hydraulic connections with the underlying Ordovician karst aquifers. Once AMD in abandoned coal mines is generated, there are only three discharge ways: outflow to the surface water; recharge to coal-bearing aquifers; leak into underlying karst aquifers. So the leakage into the underlying karst aquifers is one of the main ways of AMD discharge. This discharge capacity depends on the leakage channels between the water gathering space and the karst aquifers.

However, there are few studies on the AMD leakage through these leakage channels, such as faults and collapse columns. For example, the faults in Dahangou coal mine in Ningwu coalfield directly connect the coal-bearing aquifer with the Ordovician aquifers. There are about 450 and 400 collapse columns found in Qinshui and Xishan coalfields, respectively, which can directly form the leakage channels of AMD, and have great impact on the water quality of the underlying karst aquifers. Due to the control of other factors such as geological structure, filling material, cementation and water pressure, the research on AMD discharge channels in Shanxi abandoned coal mines is more complicated. Therefore, from the perspective of protecting Shanxi's karst water resources and drinking water safety, it is necessary to carry out research on the discharge channels of AMD in abandoned coal mines, especially the impact of AMD on Shanxi's karst water resources through faults and/or collapse columns. 


\subsection{Water Quality Migration and Transformation}

At present, research on the migration law and hydrochemical balance of AMD in Shanxi abandoned coal mines is basically theoretical. For example, Zhao et al. [51] studied the chemical composition and phase composition of AMD and its sediments in Malan coal mine in Taiyuan. Sun et al. [84] determined the content of rare earth elements in AMD, sediments and coal samples in two different mining areas in Shanxi. The previous research has not considered the participation of microorganisms, gas components, etc. Due to irreversible changes in the water-bearing medium and pollution channels of the groundwater system in Shanxi abandoned coal mines, the hydrogeological conditions have become more complex. Considering that it is more difficult to collect water and rock samples from abandoned coal mines, the research objectively faces more challenges. In fact, hydrochemistry research on the migration and transformation of AMD during water filling and water gathering has rarely attracted scholars' attention in Shanxi. Therefore, it is essential to carry out further research on the migration and transformation of AMD.

\subsection{Hydrochemistry Equilibrium}

After AMD overflows to the surface water, a new chemical equilibrium is formed. For example, the AMD from an abandoned coal mine in Yangquan coal mining area has polluted the Shandihe River Basin. According to the test results, the AMD in the basin is highly acidic with $\mathrm{pH}=2-3$, and contains the highest sulfate with $11,370 \mathrm{mg} / \mathrm{L}$, which exceeds the class III of "China Groundwater Quality Standard" (GB/T14848-2017) by 45 times, and heavy metals such as Fe, Mn, Zn, Cd exceed the standard by 1100, 510, 10, and 50 times, respectively. These data indicated that through physical and chemical reactions such as oxidation, deposition, adsorption and microbial degradation, AMD is in a new chemical equilibrium state and destroys the water ecological environment of the downstream rivers (Figure 4).

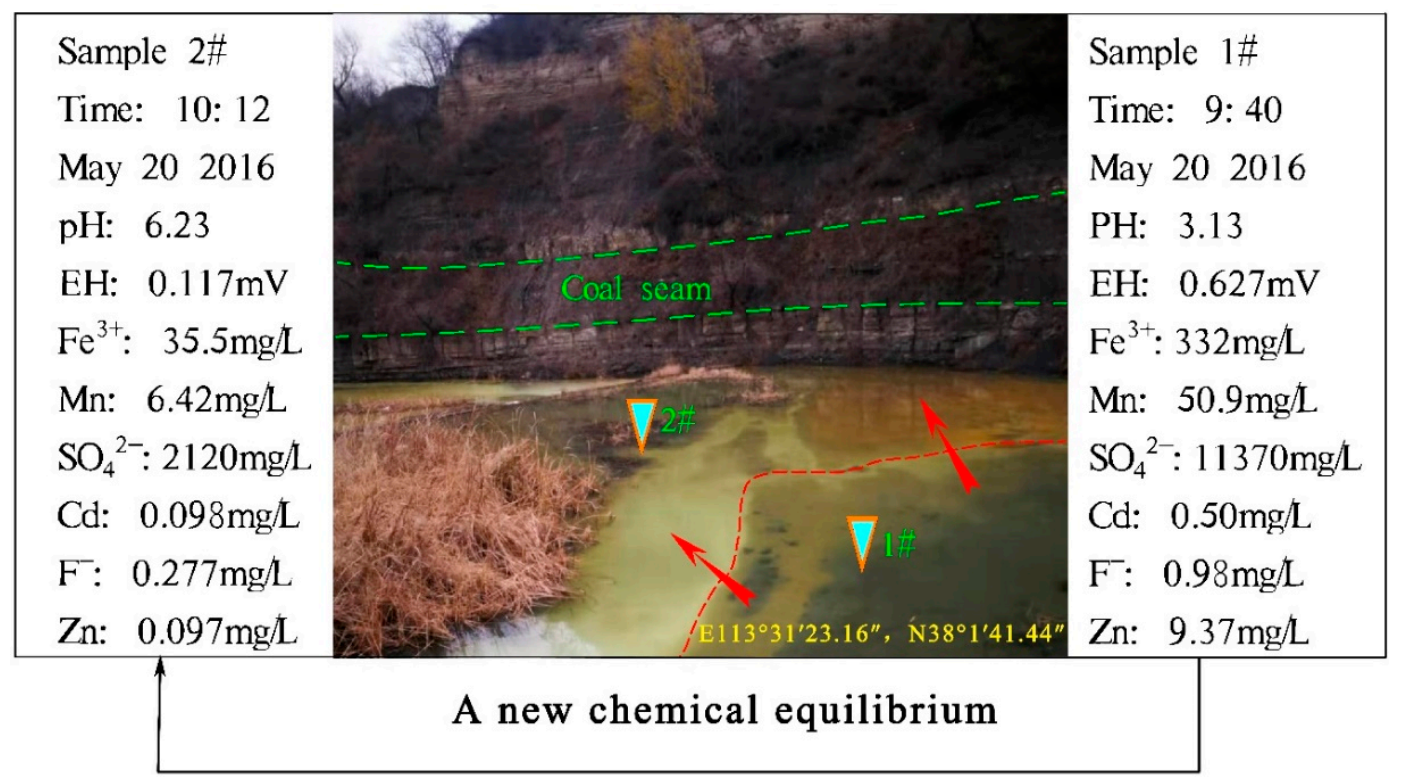

Figure 4. Acid mine drainage (AMD) in Shandi Village, Yangquan, Shanxi.

Moreover, the pressure and temperature of various gases and ion concentration of AMD have impacts on the hydrochemical equilibrium. It is a regret that there is no report on the research of AMD hydrochemical equilibrium in Shanxi abandoned coal mines. Therefore, research on the hydrochemical equilibrium of AMD under the outflow state should be strengthened. 


\subsection{Outflow Prediction of $A M D$}

After coal mines have been closed for decades or even hundreds of years, AMD's pollution to the regional water environment still exists. Due to numerous abandoned coal mines in Shanxi, it is necessary to find out which closed coal mine will be prone to AMD outflow, how long the AMD will continue to outflow, and where the AMD will outflow. The AMD outflow is affected by many factors, such as water source, water gathering space, and discharge capacity. At the same time, the AMD quantity changes over time. However, the current research cannot fully and truly reproduce the water level dynamics of AMD in abandoned coal mines. In addition, the spatial location of the discharge point is controlled by many factors such as geological structure, roadway system, coal outcrop and wellbore. Their stronger concealment increases the difficulty of research. At present, there is a lack of research on the correlation between the outflow of AMD and influencing factors in Shanxi abandoned coal mines, and no relevant researches have been carried out on the time and location of the AMD outflow. Therefore, research on the AMD outflow prediction in Shanxi abandoned coal mines should be carried out.

\subsection{Treatment}

Due to the constraints of economy and technology, the treatment method for AMD in Shanxi abandoned coal mines has to be relatively simple. For example, Yin et al. [86], Zhao et al. [51] and Liu [87] used desulfurization bacteria in natural loess and desulfurization vibrio bacteria in a sewage purification plant sludge to remove sulfate. Moreover, the neutralization precipitation method [90], sandy soil [91], Malan loess, ferrous slag and carbon steel slag [92,93], corn cob and SRB method [94], red mud [95], "Loess Wetland Plant Microbial Ecosystem" [96,97] have been used to treat AMD in Shanxi abandoned coal mines. However, all of these methods are undertaken in the laboratory and theoretical research stages, and there are still no successful cases for the AMD treatment project in Shanxi abandoned coal mines. Therefore, it is necessary to explore an efficient, inexpensive, environmental treatment technology for AMD, such as artificial wetland and Permeable Reactive Barriers (PRB) restoration technology. These technologies are widely used internationally, while national applications are more concentrated in the AMD treatment for metal mines, and the AMD treatment in Shanxi abandoned coal mines is relatively lacking. Thus, it is necessary for Shanxi to adopt a comprehensive method to treat AMD in abandoned coal mines and actively apply to the engineering practice of treating AMD.

\subsection{Management}

Currently, management policies and regulations for abandoned coal mines in Shanxi is still lacking. Coupled with the shortage of historic monitoring data of AMD pollution, the harm of AMD cannot be measured. The measures such as shaft closure and roadway blockage make it difficult to completely avoid AMD's water sources and water channels, and prevent the formation and discharge of AMD from destroying the regional water environment.

Moreover, Shanxi has not promulgated the standards and regulations for AMD management of abandoned coal mines, and has not constructed the AMD risk assessment model and early warning mechanism for abandoned coal mines. Among massive Shanxi closed coal mines, the utilization rate of AMD is extremely low. Therefore, it is urgent to strengthen research on the management, risk assessment and early warning mechanism of AMD in Shanxi abandoned coal mines.

\section{Future Research}

For the sake of avoiding further deterioration of water resources and water environment caused by AMD in Shanxi, researchers and government administrators should carry out further research on the following aspects.

(1) The regional distribution characteristics of pyrite and the occurrence law in coalbearing strata in six major coalfields of Shanxi should be actively carried out, and the 
hydraulic connections among surface water, groundwater, geological structure, waterconducting fissure zone and the formation, migration and transformation of AMD should be characterized.

(2) The researchers should improve the comprehensive detection methods of the hydrogeological conditions, water channels, water gathering spaces and roadway systems of abandoned coal mines, and promote research on the formation, migration and prediction of AMD and related environmental issues. The groundwater seepage theories and models that involve the roadway system, geological structure and primary fissures need to be explored, and the groundwater flow dynamics that are highly involved in the roadway system should be actively researched.

(3) The formation mechanism of AMD in abandoned coal mines needs to be studied, and the main modes of groundwater resources pollution caused by AMD should be summarized. It is necessary to fully consider the influence of microorganisms, gas components and other factors on the migration law of AMD in groundwater and the hydrochemical balance of abandoned coal mines. To effectively predict and prevent the generation of AMD, the oxidation of coal-based sulphate and the release of harmful elements should be clarified. Furthermore, a risk assessment model of AMD pollution needs to be constructed to provide effective support for scientific planning and decision-making.

(4) It is necessary to further identify the three issues of which coal mine will be prone to AMD outflow, how long it will continue to outflow, and where it will outflow. Research on the correlation between AMD outflow from abandoned coal mines and influencing factors should be strengthened, and relevant investigations and predictions should be carried out on these three issues of AMD. More attention should be paid to the effects of gas composition, pressure, temperature and ion concentration of AMD on the hydrochemical equilibrium during the conversion of the environment.

(5) It is necessary to actively carry out research on the application of comprehensive treatment technologies such as artificial wetlands and PRB in the active treatment of AMD in abandoned coal mines, and explore an efficient, cheap, environmental technology for AMD.

(6) With regard to management, technical guidelines for the closure of coal mines should be issued to guide coal mine closure and supervision as soon as possible. A network system for monitoring the AMD groundwater in abandoned coal mines should be established to provide effective information for AMD risk identification. Research on management, risk assessment and early warning mechanisms for the AMD in abandoned coal mines should be strengthened.

(7) To alleviate the shortage of water resources in Shanxi and ensure the safety of drinking water, the in-depth study of the hydraulic connection between the AMD in abandoned mines and karst springs should be strengthened, which will help us to achieve the sustainable development of coal, water resources, and the ecological environment.

\section{Conclusions and Recommendations}

This review gives an overview of AMD in abandoned coal mines in Shanxi, China. It critically reviews the research results of AMD from the five aspects of formation, migration, prediction, treatment and management. The relevance between the uniqueness of hydrogeological conditions of abandoned coal mines and drinking water safety were further analyzed, and governance ideas and management measures were proposed.

The review showed that sulfur-containing minerals and groundwater replenishment are the main sources of the mechanism of AMD formation, pyrite is the prerequisite, oxygen is the inducement, water is the carrier, and $\mathrm{Fe}^{3+}$ and microorganisms are the catalyst. The roadway system and geological structure are the dominant factors that control the watergathering space of AMD. The problem of abandoned coal mines has worsened the current water ecology and water environment. It has aggravated the current situation of water shortages in Shanxi, and caused ecological and environmental problems and a drinking water safety crisis, so it is necessary to conduct further research on AMD. 
The main problems in the previous research of AMD in Shanxi abandoned coal mines are: (1) The detailed investigations have never been carried out on the regional distribution characteristics of pyrite and its occurrence in coal-bearing strata in six major coalfields; hydraulic connection between AMD and surface water as well as groundwater is not emphasized. (2) Roadway systems in abandoned coal mines are often overlooked in the aspect of generalization and analyzation of AMD flow field. (3) The distribution and occurrence laws of AMD water-gathering spaces in abandoned coal mines are difficult to grasp; the water head and water accumulation coefficient in the goaf are difficult to detect as they vary in time. (4) The research on water channels between the water-gathering space and the karst aquifer such as faults and collapse columns is relatively lacking. (5) The participation of microorganisms and multi-gas components are not considered in the research of AMD migration and transformation; there is a lack of attention to the water filling and water accumulation process of AMD; and it is difficult to collect underground water samples and rock samples from abandoned coal mines. (6) The influence of gas composition, pressure, temperature and AMD ion concentration on hydrochemical equilibrium is not studied from reduction to oxidation when AMD flows out. (7) No relevant investigations have been carried out to address three issues of comparative concern: which mine will be prone to AMD outflow, how long it will continue to outflow, and where it will outflow. (8) The AMD treatments in Shanxi abandoned coal mines are basically at the stage of laboratory theoretical research; research on the restoration technology of artificial wetland and PRB is still not adequated. (9) The management policy (norms) and AMD historic monitoring data for Shanxi abandoned coal mines are relatively lacking; the research on risk identification and index systems is basically absent for risk assessment and early warning mechanisms.

The research on AMD in Shanxi abandoned coal mines should be further strengthened in the following aspects: (1) actively carry out the research on the regional distribution characteristics of pyrite in the six coalfields and its occurrence in coal-bearing strata. (2) It is necessary to improve the comprehensive detection method of AMD, explore the groundwater theory and model of abandoned coal mines involving roadway systems and primary fissures; the study of the internal relationship between geological structure and AMD gathering space through faults and/or collapse columns should be strengthened to determine the influence on karst water resources. (3) It is necessary to further strengthen research on the mechanism of AMD formation, migration and hydrochemical equilibrium under the influence of microbial action, gas composition, pressure, temperature and ion concentration, and construct a reasonable pollution risk assessment model for AMD. (4) There is an urgent need to research the following three issues: which mine will be prone to AMD outflow, how long it will continue to outflow and where it will outflow. (5) Research on artificial wetlands and PRB in the AMD treatment should be further strengthened. (6) It is necessary to advise the government to promulgate specific policy for AMD risk assessment and early warning mechanisms as soon as possible.

There are 19 major karst springs in Shanxi. Under the influence of climate change and human activities, the quantity and quality of karst water resources in these springs have been changed seriously. Some springs such as Jinci spring, Lancun spring and Gudui spring ceased to flow for many years. However, for most spring catchments, karst water resources are symbiotic with coal mines. If the AMD from abandoned coal mines continues to deteriorate, the shortage of Shanxi karst water resources will be further aggravated and will threaten the karst water ecosystem and drinking water safety. To avoid the deterioration of karst water resources in Shanxi, more attention must be attracted to focus on AMD by water resource management departments and coal-mining enterprises.

Author Contributions: Z.W., Z.Z.: Methodology, Formal analysis, Investigation, Writing-original draft, Writing—review \& editing. Y.X.: Writing—review and editing, Supervision. Y.Z.: Investigation, Supervision, Project administration, funding acquisition. All authors have read and agreed to the published version of the manuscript. 
Funding: This research was funded by the National Natural Science Fund Projects of China, grant number 41572221.

Acknowledgments: The author would be like to acknowledge the National Natural Science Foun.

Conflicts of Interest: The authors declare no conflict of interest.

\section{References}

1. Grande, J.A.; Borrego, J.; Morales, J.A.; Torre, M.L.D.L. A description of how metal pollution occurs in the tinto-odiel rias (huelva-spain) through the application of cluster analysis. Mar. Pollut. Bull. 2003, 46, 475-480. [CrossRef]

2. Cravotta, C.A.; Brightbill, R.A.; Langland, M.J. Abandoned mine drainage in the swatara creek basin, southern anthracite coalfield, Pennsylvania, USA: 1. stream water quality trends coinciding with the return of fish. Mine Water Environ. 2010, 29, 176-199. [CrossRef]

3. Gammons, C.H.; Duaime, T.E.; Parker, S.R.; Poulson, S.R.; Kennelly, P.J. Geochemistry and stable isotope investigation of acid mine drainage associated with abandoned coal mines in central Montana, USA. Chem. Geol. 2010, 269, 100-112. [CrossRef]

4. Verb, R.G.; Casamatta, D.A.; Vis, M.L. Effects of different vegetative substrates on algal composition in vernal mesocosms. Hydrobiologia 2001, 455, 111-120. [CrossRef]

5. Pinto, M.M.S.C.; Silva, M.M.V.G.; Neiva, A.M.R. Pollution of Water and Stream Sediments Associated with the Vale De Abrutiga Uranium Mine, Central Portugal. Mine Water Environ. 2004, 23, 66-75. [CrossRef]

6. Cabral Pinto, M.; Silva, M.M.; Neiva, A.M.; Guimarães, F.; Silva, P.B. Release, Migration, Sorption, and (Re)Precipitation of U during Peraluminous Granite Alteration under Oxidizing Conditions in Central Portugal. Geosciences 2018, 8, 95. [CrossRef]

7. Neiva, A.M.R.; de Carvalho, P.C.S.; Antunes, I.M.H.R.; dos Santos, A.C.T.; da Silva Cabral-Pinto, M.M. Spatial and temporal variability of surface water and groundwater before and after the remediation of a Portuguese uranium mine area. Geochemistry 2015, 75, 345-356. [CrossRef]

8. Netshitungulwana, R.; Yibas, B.; Novhe, O.; Motlakeng, T. Stream sediment geochemistry of the areas impacted by mining around Emalahleni (formerly known as Witbank), South Africa: Fingerprinting AMD potential point sources. Annu. Int. Mine Water Assoc. Conf. Reliab. Mine Water Technol. 2013, 118, 122-134. [CrossRef]

9. McCarthy, T.S. The impact of acid mine drainage in South Africa. South Afr. J. Sci. 2011, 107, 1-7. [CrossRef]

10. Geldenhuis, S.; Bell, F.G. Acid mine drainage at a coal mine in the eastern Transvaal, South Africa. Environ. Earth Sci. 1998, 34, 234-242. [CrossRef]

11. Equeenuddin, S.M.; Tripathy, S.; Sahoo, P.K.; Panigrahi, M.K. Hydrogeochemical characteristics of acid mine drainage and water pollution at Makum Coalfield, India. J. Geochem. Explor. 2010, 105, 75-82. [CrossRef]

12. Kim, J.H.; Chon, H. Pollution of a water course impacted by acid mine drainage in the Imgok creek of the Gangreung coal field, Korea. Appl. Geochem. 2001, 16, 1387-1396. [CrossRef]

13. Ribeiro, J.; Silva, E.F.; Li, Z.; Ward, C.R.; Flores, D. Petrographic, mineralogical and geochemical characterization of the Serrinha coal waste pile (Douro Coalfield, Portugal) and the potential environmental impacts on soil, sediments and surface waters. Int. J. Coal Geol. 2010, 83, 456-466. [CrossRef]

14. Zhang, N.; Kan, J.; Wang, M. Current Situation and Distribution Characteristics of Waste Coal Mine Resources in China. Coal Econ. Res. 2019, 39, 4-8. (In Chinese)

15. Gao, B. Occurrence Characteristics and Biodegradation Mechanism of Polycyclic Aromatic Hydrocarbon in Closed Coal Mine. Ph.D. Thesis, China University of Mining and Technology, Xuzhou, China, 2019. (In Chinese)

16. Shang, Y.; Qi, P. Study on Environmental Negative Effect and Control of Waste Coal Mine. Coal Eng. 2018, 50, 147-150. (In Chinese) [CrossRef]

17. $\mathrm{Wu}, \mathrm{Q}$; $\mathrm{Li}, \mathrm{S}$. Positive and negative environmental effects of closed mines and its countermeasures positive and negative environmental effects of closed mines and its countermeasures. J. China Coal Soc. 2018, 43, 21-32. (In Chinese) [CrossRef]

18. Banks, S.B.; Banks, D. Abandoned mines drainage: Impact assessment and mitigation of discharges from coal mines in the UK. Eng. Geol. 2013, 60, 31-37. [CrossRef]

19. Wood, S.C.; Younger, P.L.; Robins, N.S. Long-term changes in the quality of polluted minewater discharges from abandoned underground coal workings in Scotland. Q. J. Eng. Geol. Hydrogeol. 1999, 32, 69-79. [CrossRef]

20. Zhang, H.; Zhu, S.; Li, X.; Li, T.; Meng, F. Research on the height of water flowing fractured zone of overburden strata in fully-mechanized top-coal caving. Ind. Mine Autom. 2015, 41, 10-14. (In Chinese) [CrossRef]

21. Wu, J.; Zeng, X. Numerical Simulation of Groundwater Pollution in Waste Mine; China Water Conservancy and Hydropower Press: Beijing, China, 2015. (In Chinese)

22. Lv, H.; Liu, H.; Ma, Z.; Xu, P. Formation and influential factors of Zibo City Hongshan and Zhaili coalmines underground water cross strata pollution. Coal Geol. China 2005, 17, 24-27.

23. Brake, S.S.; Connors, K.A.; Romberger, S.B. A river runs through it: Impact of acid mine drainage on the geochemistry of West Little Sugar Creek pre- and post-reclamation at the Green Valley coal mine, Indiana, USA. Environ. Geology. 2001, 40, 1471-1481. [CrossRef]

24. Fang, J.; Hasiotis, S.T.; Gupta, S.D.; Brake, S.S.; Bazylinski, D.A. Microbial biomass and community structure of a stromatolite from an acid mine drainage system as determined by lipid analysis. Chem. Geol. 2007, 243, 191-204. [CrossRef] 
25. Gammons, C.H.; Brown, A.; Poulson, S.R.; Henderson, T.H. Using stable isotopes (S, O) of sulfate to track local contamination of the madison karst aquifer, montana, from abandoned coal mine drainage. Appl. Geochem. 2013, 31, 228-238. [CrossRef]

26. Mokgehle, T.M.; Gitari, W.M.; Tavengwa, N.T. Synthesis of di-carboxylic acid functionalized zeolites from coal fly ash for Cd (II) removal from acid mine drainage using column studies approach. J. Environ. Chem. Eng. 2019, 7, 103473. [CrossRef]

27. Lazareva, E.V.; Myagkaya, I.N.; Kirichenko, I.S.; Gustaytis, M.A.; Zhmodik, S.M. Interaction of natural organic matter with acid mine drainage: In-situ accumulation of elements. Sci. Total Environ. 2019, 660, 468-483. [CrossRef]

28. Nassery, H.R.; Alijani, F. The Effects of an Abandoned Coal Mine on Groundwater Quality in the Science and Research Park (SRP) of Shahid Beheshti University, Zirab (Northern Iran). Mine Water Environ. 2014, 33, 266-275. [CrossRef]

29. Jiang, Y.; Liu, C.; Tao, F. Sulfur isotope composition characters of Wujiang river water in Guizhou province. Adv. Water Sci. 2007, 18, 558-565. (In Chinese) [CrossRef]

30. He, J.; Li, W.; Liu, J.; Chen, S.; Frost, R.L. Investigation of mineralogical and bacteria diversity in Nanxi River affected by acid mine drainage from the closed coal mine: Implications for characterizing natural attenuation process. Spectrochim. Acta Part A Mol. Biomol. Spectrosc. 2019, 217, 263-270. [CrossRef]

31. Sun, W.; Xiao, T.; Sun, M.; Dong, Y.; Ning, Z.; Xiao, E.; Tang, S.; Li, J. Diversity of the Sediment Microbial Community in the Aha Watershed (Southwest China) in Response to Acid Mine Drainage Pollution Gradients. Appl. Environ. Microbiol. 2015, 81, 4874-4884. [CrossRef]

32. Lottermoser, B.G. Mine Wastes: Characterization, Treatment and Environmental Impacts; Springer: Berlin/Heidelberg, Germany, 2010. [CrossRef]

33. Wang, Y.; Zhang, R.; Wu, P.; Xia, Y.; Song, C.; Wu, Y. Sulfate migration and transformation in relation to iron in acid mine drainage: A case study from the waste coal mine area, Zhijin Country, Guizhou Province. Chin. J. Ecol. 2018, 37, 210-216. (In Chinese) [CrossRef]

34. Grodner, M.W. A Regional, 3-D Computer-based Sedimentological Model of the Permian Witbank Coalfield, South Africa. Master's Thesis, Rand Afrikaans University, Johannesburg, South Africa, 2002. Unpublished. Available online: http:/ /hdl.handle. net/10210/1962 (accessed on 28 January 2019).

35. Bernd, E. Groundwater monitoring and isotope investigation of contaminated wastewater from an open pit mining lake. Environ. Geosci. 1998, 5, 156-161. [CrossRef]

36. Xu, X. Simulation Study on Water-Rock-Gas Reaction in Closed Coal Mine. Ph.D. Thesis, China University of Mining and Technology, Beijing, China, 2017. (In Chinese)

37. Zhang, Z. Analysis of water accumulated course in abandoned coal mine. West-China Explor. Eng. 2004, 10, 86-87. (In Chinese) [CrossRef]

38. Bi, Y.; Wu, J.; Wang, G.; Zhai, X.; Zhang, H.; Huang, K. Analysis of water-filling process in goaf of closed mine. Ind. Mine Autom. 2018, 44, 53-57. (In Chinese) [CrossRef]

39. Zhong, Q.; Liu, L.; Yang, X.; Gu, K.; Deng, W. Prediction and Impact of Groundwater Rise in Closed Pit Mines. Chem. Manag. 2019, 8, 137-138. (In Chinese) [CrossRef]

40. Pan, Y.; Liu, Y.; Zeng, X.; Wu, J. Numerical simulation of groundwater flow field evolution in abandoned mine in the east Xuzhou. Hydrogeol. Eng. Geol. 2017, 44, 52-56. (In Chinese) [CrossRef]

41. Zhou, J.; Hu, W.; Liu, Y. Analysis on Water Content Medium Field Features and Water Flow Motion Features in Abandoned Mine. Coal Sci. Technol. 2011, 39, 107-110. (In Chinese)

42. Sun, T. Study on the Water Level Restoration Process and Its Influence on Regional Groundwater after the Closure of Quantou Mine in Fengfeng Mining Area. Ph.D. Thesis, China University of Geosciences, Beijing, China, 2014. (In Chinese)

43. Gitari, W.M.; Petrik, L.F.; Etchebers, O.; Key, D.; Okujeni, C. Utilization of fly ash for treatment of coal mines wastewater: Solubility controls on major inorganic contaminants. Fuel 2008, 87, 2450-2462. [CrossRef]

44. Song, J.; Fallgren, P.H.; Morris, J.M.; Cooper, J.S. Source treatment of acid mine drainage at a backfilled coal mine using remote sensing and biogeochemistry. Water Air Soil Pollut. 2008, 188, 205-212. [CrossRef]

45. Rezaie, B.; Anderson, A. Sustainable resolutions for environmental threat of the acid mine drainage. Sci. Total Environ. 2020, 717, 137211. [CrossRef]

46. Zhang, L.; Xie, M.; Pang, J.; Shi, Y.; Yang, M.; Pan, W. Research on modified fly ash for high iron and high manganese acid mine drainage treatment. In Proceedings of the 2011 International Conference on Remote Sensing, Environment and Transportation Engineering, Nanjing, China, 24-26 June 2011; pp. 7053-7056. (In Chinese) [CrossRef]

47. Liu, P.; Sun, Y. Discussion on Groundwater Pollution Caused by Abandoned Mines and Its Controlling Techniques. Min. R D 2011, 31, 91-94. (In Chinese)

48. Wei, T.; Yu, Y.; Hu, Z.; Cao, Y.; Gao, Y.; Yang, Y.; Wang, X.; Wang, P. Research Progress of Acid Mine Drainage Treatment Technology in China. Appl. Mech. Mater. 2013, 409-410, 214-220. [CrossRef]

49. Jiang, C.; Gao, X.; Hou, B.; Zhang, S.; Zhang, J.; Li, C.; Wang, W. Occurrence and Environmental Impact of Coal Mine Goaf Water in Karst Areas in China. J. Clean. Prod. 2020, 275, 123813. [CrossRef]

50. Xu, G.; Yue, M.; Yan, J.; Jiang, Q.; Liang, X. Analysis on chemical property of acid mine water and prevention in Sitai coal mine. Coal Sci. Technol. 2007, 35, 111-113. (In Chinese)

51. Zhao, F.; Sun, H.; Li, W. Migration of hazardous elements in acid coal mine drainage. J. China Coal Soc. 2007, 32, 261-266. (In Chinese) 
52. Liang, Y.; Zhao, C.; Tang, C.; Shen, H.; Wang, Z.; Guo, F. Reanalysis of spring water and its pollution causes of the Niangziguan spring in Shanxi. Carsologia Sin. 2017, 36, 633-640. (In Chinese)

53. Zhang, Z.; Wang, Z.; Xu, Y.; Zhang, Y.; Guo, L.; Zheng, Q.; Tang, L. Quantitative study on the changes of karst groundwater level and hydrochemistry in Jinci Spring catchment, Shanxi, China. Expo Health 2019, 12, 513-525. [CrossRef]

54. Lei, L. Analysis of factors of coal seam water filling and prevention of mine water hazard: An example of Xishan Ximing Coal Mine. Shanxi Sci. Technol. 2011, 6, 20-21. (In Chinese)

55. Shen, L. Analysis of factors of coal seam water filling and prevention of mine water hazard: A case study of Xishan Duerping Coal Mine. Shanxi Sci. Technol. 2011, 2, 29-31. (In Chinese)

56. Zhao, Z.; Zhang, Z.; Yin, X. Study on characteristics and formation mechanism of acid mine wastewater in Xishan coalfield, Taiyuan. Geotech. Investig. Surv. 2008, 2, 31-33. (In Chinese)

57. Qiao, X.; Li, G.; Zhou, J.; Du, J.; Du, C.; Sun, Z.; Wu, R. Analysis of influence of coal exploitation on water resources and environment: A case study of coal exploitation in Xishan of Taiyuan City. Water Resour. Prot. 2010, 26, 49-52. (In Chinese)

58. Li, Z.; Wang, J. Future Destruction and Pollution of Groundwater Resources in Shanxi from Coal Mining. Coal Geol. China 2019, 31, 42-44. (In Chinese)

59. Zhang, Z.; Xu, Y.; Wang, Z.; Zhang, Y.; Zhu, X.; Guo, L.; Zheng, Q.; Tang, L. Ecological restoration and protection of Jinci Spring in Shanxi, China. Arab J. Geosci. 2020, 13, 744. [CrossRef]

60. Yang, H. Evaluation of the Influence of Old Mine Water in Shandi River on the Water Quality of NiangziGuan Spring. Shanxi Water Resour. 2017, 8, 6-7. (In Chinese)

61. Zhang, Z.; Xu, Y.; Zhang, Y.; Cao, J. Review: Karst springs in Shanxi, China. Carbonates Evaporites 2019, 34, 1213-1240. [CrossRef]

62. Wang, T. Influence of Coal Mining on Water Quality of Karst Groundwater in Niangziguan Spring Area. Groundwater 2015, 37, 34-35. (In Chinese)

63. Huo, J.; Zhao, C.; Liang, Y.; Wang, T.; Tang, C.; Wang, W.; Shen, H. Characteristic and Causes Analysis in the Runoff-Drainage Area of Niangziguan Spring. Geol. Sci. Technol. Inf. 2015, 34, 147-152. (In Chinese)

64. Li, Y.; Wang, Y.; Liu, J.; Luo, Z. Pollution Ananlysis of $\mathrm{SO}_{4}{ }^{2-}, \mathrm{Ca}^{2+}, \mathrm{Mg}^{2+}$ in Karst Water in Niangziguan Spring Area. Geol. Sci. Technol. Inf. 1998, 17, 111-114. (In Chinese)

65. Liu, Q. Study on Formation Mechanism and Influence of Acid Water in the Old Goaf in Shandi River Basin of Yangquan City. Ph.D. Thesis, Taiyuan University of Technology, Taiyuan, China, 2018. (In Chinese)

66. Deng, C.; Yue, M.; Wang, L.; Wu, F. Experimental study on the effects of Thiobacillus ferrooxidans on the supergenesis of pyrite under weathering conditions. J. Saf. Environ. 2013, 13, 83-89. (In Chinese)

67. Kirby, C.S.; Elderbrad, J.A. Field determination of $\mathrm{Fe}^{2+}$ oxidation rates in acid mine drainage using a continuously-stirred tank reactor. Appl. Geochem. 1998, 13, 509-520. [CrossRef]

68. Liu, D. The Study of Coal Petrology and Coal Geochemistry in Permo-Carboniferous Coal from Datong Coalfield. Ph.D. Thesis, Taiyuan University of Technology, Taiyuan, China, 2007. (In Chinese)

69. Tiwary, R.K. Environmental impact of coal mining on water regime and its management. Water Air Soil Pollut. 2001, 132, 185-199. [CrossRef]

70. Lambert, D.C.; Mcdonough, K.M.; Dzombak, D.A. Long-term changes in quality of discharge water from abandoned underground coal mines in Uniontown Syncline, Fayette County, PA, USA. Water Res. 2004, 38, 277-288. [CrossRef] [PubMed]

71. Zhang, Z.; Zhang, Y.; Zhao, Z.; Zhang, L. Similar simulation of overlying rock movement and surface deformation behavior with multi-coal seam mining. Hydrogeol. Eng. Geol. 2011, 38, 130-134. (In Chinese)

72. Zhang, Q.; Zhou, J.; Lin, S.; Wei, D.; Zhang, L.; Yuan, L. Characteristics and causes of groundwater pollution after Hongshan-Zhaili Mine closure in Zibo. Saf. Environ. Eng. 2015, 22, 27-32. (In Chinese) [CrossRef]

73. Kang, X. Research on the Form Mechanism of Left-Over Areas Water and Disposal. Ph.D. Thesis, Taiyuan University of Technology, Taiyuan, China, 2012. (In Chinese)

74. Li, M. Study on Ordovician Fengfeng Formation Water Yield Property Impacting Factor in Shanxi Province. Coal Geol. China 2018, 30, 55-60. (In Chinese)

75. Xiong, C.; Wang, J. Research on Water Accumulating Volume in Mine Gob. Min. Saf. Environ. Prot. 2005, 32, 10-11. (In Chinese) [CrossRef]

76. Di, X. Distribution characteristics and water bursting forecast of the accumulated water in goaf areas in the Tongxin mine field. Hydrogeol. Eng. Geol. 2007, 3, 24-27. (In Chinese)

77. Zhu, R. Analysis of water-filling factors and measures for prevention and control of water hazards in Shanxi Ruitaijing Coal Mine. J. Yanan Coll. Educ. 2014, 28, 130-132. (In Chinese) [CrossRef]

78. Wen, J.; Zhang, Y. Application of Integrated Electric Prospecting on Gob Ponding Area in Southeastern Shanxi Province. Coal Geol. China 2017, 29, 73-75. (In Chinese) [CrossRef]

79. Xu, X. Application of the transient electromagnetic method to flooding survey in a coal mining area of Shanxi Province. Geol. Explor. 2019, 55, 579-584. (In Chinese)

80. Pope, J.; Newman, N.; Craw, D.; Trumm, D.; Rait, R. Factors that influence coal mine drainage chemistry West Coast, South Island, New Zealand. N. Z. J. Geol. Geophys. 2010, 53, 115-128. [CrossRef] 
81. Ludwig, B.; Khanna, P.; Balkenhol, R.; Friedrich, G.; Dohrmann, R. Pyrite oxidation in a sediment sample of an open-cut brown coal mine: Mineral formation, buffering of acidity and modeling of cations and sulfate. J. Plant Nutr. Soil Sci. 2015, 162, 499-509. [CrossRef]

82. Perez-Lopez, R.; Quispe, D.; Castillo, J.; Nieto, J.M. Acid neutralization by dissolution of alkaline paper mill wastes and implications for treatment of sulfide-mine drainage. Am. Miner. 2011, 96, 781-791. [CrossRef]

83. Iii, C.A.C. Dissolved metals and associated constituents in abandoned coal-mine discharges, Pennsylvania, USA. Part 2: Geochemical controls on constituent concentrations. Appl. Geochem. 2008, 23, 203-226. [CrossRef]

84. Sun, H.; Zhao, F.; Li, W.; Li, R.; Ge, X. Geochemical Characteristics of Acid Mine Drainage and Sediments from Coal Mines. J. China Univ. Min. Technol. 2007, 36, 221-226. (In Chinese)

85. Wen, S. Research and Application of Calculation Method for Goaf Water Accumulation Quantity. Energy Energy Conserv. 2019, 12, 180-181. (In Chinese)

86. Yin, X. The Experimental Research on the Disposition of Acid Coal Mine Drainage by SRB. Ph.D. Thesis, Taiyuan University of Technology, Taiyuan, China, 2007. (In Chinese)

87. Liu, J. The Experimental Research on the Treatment of Acid Mine Drainage by Indigenous Microorganism in Loess. Ph.D. Thesis, Taiyuan University of Technology, Taiyuan, China, 2008. (In Chinese)

88. Yang, J.; Liu, J.; Gong, J.; Yin, X. The Experimental Study on Biological Treatments of Acid Coal Mine Drainage in the Natural Coal Mine Drainage Pit. J. Taiyuan Univ. Technol. 2008, 39, 307-310. (In Chinese) [CrossRef]

89. Zhao, Z.; Wu, S.; Chen, Y. Experimental study on the disposal of coal acid mine drainage with loess. Geotech. Investig. Surv. 2012, 40, 38-41. (In Chinese)

90. Zhou, Z.; Zhao, L.; Ge, X.; Zhao, S.; Jiang, Z.; Wang, D. Optimizing iron removal of acidic mine draining water in neutralization and precipitation process. Chin. J. Environ. Eng. 2014, 8, 2347-2352. (In Chinese)

91. Wu, A.; Zhang, Y.; Zheng, Q.; Yang, J.; Zhang, Z. Experimental Study of Adsorption Efficiency to $\mathrm{SO}_{4}{ }^{2-}$ in $\mathrm{Abandoned} \mathrm{Mine}^{2}$ Water by Sandy Soil. Min. Saf. Environ. Prot. 2018, 45, 6-9. (In Chinese)

92. Zheng, Q.; Zhang, Y.; Li, Y.; Zhang, Z.; Shi, H. Adsorption of sulfate from acid mine drainage in northwestern china using malan loess. Arab. J. Geosci. 2019, 12, 348. [CrossRef]

93. Zheng, Q.; Zhang, Y.; Zhang, Z.; Li, H.; Wu, A.; Shi, H. Experimental research on various slags as a potential adsorbent for the removal of sulfate from acid mine drainage. J. Environ. Manag. 2020, 270, 110880. [CrossRef] [PubMed]

94. Wan, Y.; Li, H. Biological Treatment for Acid Mine Drainage by Using Corncob as Carbon Source. Ind. Saf. Environ. Prot. 2004, 30, 11-15. (In Chinese) [CrossRef]

95. Lu, Y.; Wang, M.; Huang, G.; Dong, X. Experimental Study on Treatment to Acid Mine Drainage by Modified Red Mud. Non-Met. Mines 2018, 41, 15-18. (In Chinese) [CrossRef]

96. Wang, M.; Zhao, Z.; Wang, Y. The Treatment of Coal Mine's Acidic Wastewater. Sci/Tech Inf. Dev. Econ. 2005, 15, 193-194. (In Chinese) [CrossRef]

97. Zhang, Z. The Environment Capacity and Experimental Research of the Treatment for Acid Mine Drainage with Loess. Ph.D. Thesis, Taiyuan University of Technology, Taiyuan, China, 2007. (In Chinese) 